\title{
ON CREATIONISM IN THE ASTRONOMY CLASSROOM
}

\author{
Philip J. Sakimoto \\ Department of Astronomy, Whitman College, Walla Walla, Washington 99362 U.S.A.
}

Recently in the United States, a small but vocal group of citizens has been promoting a view known as "creationism," the assertion that the universe and everything in it was created in six days by divine fiat as suggested by a literalist interpretation of the Christian Bible. In a now common variant, "scientific creationism" or "creation-science," they assert further that this version of creation is proven true on "scientific" evidence alone, independent of any religious underpinnings. Legislation requiring the teaching of creation-science alongside of evolution in the public schools has been proposed in over twenty states; in Louisiana and Arkansas such legislation was passed, although it was later struck down by federal courts as a violation of the separation of church and state. ${ }^{1,2,3,4}$

Astronomers cannot afford to ignore the efforts of creation-scientists: like it or not, the movement has tainted the perceptions of science and religion that students bring to the classroom. Students from conservative Christian backgrounds are sometimes shy of legitimate science, fearing that science is somehow "antiChristian." Students with strictly rationalistic/scientific world views sometimes scoffingly equate creation-science with all of Christianity, leading to potentially hostile relations in the classroom. In both cases, preconceived notions can hamper the spirit of free-flowing inquiry we seek in academe.

At Whitman College (a small, secular, undergraduate, liberal arts college in the Pacific Northwest), I have developed a sotto voce approach to addressing creationscience within the framework of a standard introductory astronomy class. With it, I hope to create a more honest inquiry into (and possibly acceptance of) legitimate scientific and theological perspectives.

On the first day of class, I assign a brief homework essay in which the students assess their religious or philosophical world views to see if they anticipate any conflicts between those views and concepts in astronomy. In making the assignment, which is taken directly from the textbook ${ }^{5}$, I emphasize that the views expressed will have no bearing on the grade given; the grade is based solely on thoughtfulness and exposition style. I do not comment on the responses at this juncture; rather, I proceed with the class as if nothing significant has yet gone on. The students, however, have been forced to explicitly recognize their a priori prejudices; they must now wrestle openly with them as the class progresses, rather than holding them as unseen or unstated stumbling blocks to learning.

The next step is to teach my standard general astronomy class with an emphasis on the underlying methodology of the science: how do we know what we know? For example, I emphasize the classical "proofs" that the Earth is round, the 
connections between observations and models in stellar evolution, and the observational evidence for the big bang. Exams are essay-style, forcing students to actively engage in the scientific process. The purpose here is to establish firmly the methodologies of normative science; it is useless to talk about the methodological flaws in creation-science until the students have experienced normal science first-hand.

At the end of class, I give a single lecture on creation-science. The purpose of this lecture is not so much to "resolve the conflict" as it is to show by tracing roots of the arguments that there really is no need to have a conflict at all. I begin by quoting verbatim the tenets of creation-science as defined in Section $4 \mathrm{a}$ of the Arkansas Creation Science Statute, ${ }^{3,6}$ reviewing the institutional structure of the socalled "creation research institutes," $6,7,8$ and quoting the statement of faith required for membership in the Creation Research Society in Ann Arbor, Michigan. ${ }^{6}$ This unambiguously demonstrates the literalist Biblical origins of the creation-science movement.

I then trace the generally accepted Biblical origins of Genesis, beginning with the Babylonian mythopoeic tradition from which the creation story in Genesis is taken. ${ }^{9}$ I emphasize that the intent of this story was to elucidate the relations between God, the created world, and human beings; it was never intended or seen as a scientific view of how the world was created. ${ }^{10,11,12,13}$ I then review the history of the creationism movement, showing that it is a relatively recent and fallacious deviation from mainstream theology with roots in the "common sense" philosophy of John Witherspoon and Samuel Stanhope Smith. ${ }^{14}$ My intent here is to show that (1) creationism has no basis in mainstream theology and (2) it is quite possible (and normative in theological circles) to believe in a world created by God without ascribing to the version of creation touted by creation-scientists.

With those theological aspects addressed, I turn to the scientific aspects of creation-science. I do not attempt a point-by-point rebuttal of creation-scientists' "scientific" arguments: life is too short to track down all of their fallacies. Instead, I criticize their methodology. They take a "two models" approach, insinuating that evidence against evolution is evidence for creationism. They use flawed argumentative techniques, including straw-man arguments, misapplication of physical laws, gross extrapolation, self-contradiction, and, in one case of which I am aware, false data. ${ }^{15}$ They do not make their work available for critique by the scientific community: a recent survey of 135,000 manuscripts submitted to 68 scientific, technical, and education journals over a three-year period found only 5 manuscripts dealing with the creationist advances of which, due to poor presentation styles and failure to follow accepted scientific methodologies, none had been accepted for publication at the time of the survey. ${ }^{16}$ In short, there is no point in considering the scientific arguments for creationism since there is no science in the arguments.

Together, these two lines of analysis show that creation science has no legitimacy in either scientific or theological circles. To date, I have received no objections to my treatment of the subject, nor any direct rebuttals to my analyses. This is not surprising since my approach is identical to that which I use for all other subjects: I give a frank analysis based on the consensus of recognized authorities in 
the field. Students are by and large grateful to have creation science treated openly and honestly. In some cases, previously dogmatic Christians are led to a broader understanding of the role of science in modern theology. In other cases, previously anti-Christian students gain a greater sensitivity to the religious dilemma of strict creationists. Those who previously accepted both Christianity and modern science are affirmed in their beliefs. For myself, I am grateful for the opportunity to quiet some of the false antagonism between science and the Christian faith. Perhaps this will clear the path for those who might wish to pursue the wealth of scholarship now available on the legitimate relations between modern theology and the natural sciences. ${ }^{17,18,19,20}$

\section{References}

1. Roland Mushat Frye, "Creation Science Against the Religious Background," in Is God a Creationist?: The Religious Case Against Creation-Science, ed. R.M. Frye (New York: Charles Scribner's Sons, 1983), p. 1.

2. Joseph Palca, "No Go for the Creationists," Nature, 327, 645, 1987.

3. Robert W. Hanson, ed., Science and Creation: Geological, Theological, and Educational Perspectives (New York: Macmillan Publishing Company, 1986), Appendices A \& B.

4. Paul Reidinger, "Creationism in the Classroom," Amer. Bar Assoc. J., 72, Dec. 1, 1986, p. 66.

5. William K. Hartmann, Astronomy: The Cosmic Journey, fth ed, (Belmont, CA: Wadsworth, 1987), p. 4.

6. Science (News and Comments section), 215, 143, 1982.

7. Dorothy Nelkin, "Science, Rationality, and the Creation/Evolution Dispute," in Science and Creation: Geological, Theological, and Educational Perspectives, ed. R.W. Hanson (New York: Macmillan Publishing Company, 1986), p. 33.

8. Stanley L. Weinberg, "Creationism in Iowa: Two Defense Strategies," in Science and Creation: Geological, Theological, and Educational Perspectives, ed. R.W. Hanson (New York: Macmillan Publishing Company, 1986), p. 55.

9. Bernhard W. Anderson, ed., Creation in the Old Testament (Philadelphia: Fortress Press, 1984), especially for the articles by Hermann Gunkel and Gerhard von Rad.

10. Bruce Vawter, "Creationism: Creative Misuse of the Bible," in Is God a Creationist?: The Religious Case Against Creation-Science, ed. R.M. Frye (New York: Charles Scribner's Sons, 1983), p. 71.

11. Conrad Hyers, "Biblical Literalism: Constricting the Cosmic Dance," in Is God a Creationist?: The Religious Case Against Creation-Science, ed. R.M. Frye (New York: Charles Scribner's Sons, 1983), p. 95.

12. Nahum M. Sarna, "Understanding Creation in Genesis," in Is God a Creationist?: The Religious Case Against Creation-Science, ed. R.M. Frye (New York: Charles Scribner's Sons, 1983), p. 155.

13. Bernhard W. Anderson, "The Earth is the Lord's: An essay on the Biblical 
Doctrine of Creation," in Is God a Creationist?: The Religious Case Against Creation-Science, ed. R.M. Frye (New York: Charles Scribner's Sons, 1983), p. 176.

14. James B. Miller and Dean R. Fowler, "What's Wrong with the Creation/Evolution Controversy?," CTNS Bulletin (Center for Theology and the Natural Sciences, Berkeley, CA), v. 4, Autumn 1984.

15. Examples of such flawed arguments are readily apparent to any practicing scientist who reads those aspects of creation-science literature touching on areas with which he or she is familiar. See, for example, The Scientific Case for Creation, or Scientific Creationism, both by Henry M. Morris and available from Creation Life Publishers, P.O. Box 15666, San Diego, CA 92115. The now-disavowed case of false data involved an alleged fossilized human footprint found next to a dinosaur footprint in a Texas riverbed. The human footprint turned out to be recently chiseled into the ground. I do not have references to this incident, and I would appreciate any documentation which readers can provide.

16. Eugenie Scott and Henry Cole, Quat. Rev. Biol., 60, 21, 1985; quoted by Roger Lewin, "Evidence for Scientific Creationism?," Science, 228, 837, May 17, 1985.

17. Pope John Paul II, "Science and Christianity," in Is God a Creationist?: The Religious Case Against Creation-Science, ed. R.M. Frye (New York: Charles Scribner's Sons, 1983), p. 141.

18. Ian G. Barbour, Issues in Science and Religion, (New York: Harper and Row, 1971).

19. Ernan McMullin, ed., Creation and Evolution (Notre Dame: University of Notre Dame Press, 1985).

20. See also any issue of Zygon: The Journal of Science and Religion, or the CTNS Bulletin (Center for Theology and the Natural Sciences, Berkeley CA).

\section{Discussion}

L.A. Marschall: What fraction of students seem "grievously wounded" by your course? What is their reaction?

P.J. Sakimoto: I am not aware of any students that are "grievously wounded." This is because I am careful not to denigrate anyone's faith; rather, I encourage them into a deeper understanding of their faith. Judging from the responses to open-ended exam questions, a surprisingly large number of students - perhaps 20 to $30 \%-$ report that as a result of the course they are re-thinking their previous understanding of creation while holding firmly to their belief in God. Others - perhaps the majority - report no change in their views (they were mostly "evolutionists" already), but some of them mention a new-found sympathy for (but not belief in) the religious motivations of strict creationists. 